\title{
Influence of hydrocolloids addition (carboxymethylcellulose and guargum) on some quality attributes of wheat and high quality cassava flour and its bread making potentials
}

\author{
Olatidoye, O.P. ${ }^{*}$, Shittu, A. ${ }^{2}$, Sobowale, S.S. ${ }^{3,4}$, Olayemi, W.A..$^{5}$, Adeluka, I.F. ${ }^{6}$ \\ ${ }^{1,6}$ Department of Food Technology, Yaba College of Technology, P.M.B.2011, Yaba, Nigeria \\ ${ }^{2}$ Department of Science Education, Yaba College of Technology, P.M.B.2011, Yaba, Nigeria \\ ${ }^{3}$ Department of Food Technology, Moshood Abiola Polytechnic, Abeokuta, Ogun State, Nigeria \\ ${ }^{4}$ Department of Food Technology, Mountain top University, Ibafo, Ogun State, Nigeria \\ ${ }^{5}$ Department of Agricultural Technology, Yaba College of Technology, P.M.B2011, Yaba, Lagos, Nigeria
}

*Corresponding author: waleolatidoye@gmail.com

\begin{abstract}
High quality cassava flour (HQCF) is now widely used production of baked foods in Nigeria but bread quality is impaired when it is used in the bread formulation. In order to overcome this problem, six breads samples were produced from wheat/HQCF/hydrocolloid:T $100 \%$ wheat flour(control); $T_{1}$ 90:9:CMC; $T_{2}$ 90:9:GG; $T_{3}, 80: 18: C M C ; T_{4}, 80: 18: G G ; T_{5} 70: 27: C M C ; T_{6} 70: 27: G G$. The flour blends were analyzed for functional, colour and pasting properties while breads characteristics and sensory evaluation were performed in order to assess effect of hydrocolloids on bread. The results showed composite flour with hydrocolloids had the highest bulk density $(0.704 \mathrm{~g} / \mathrm{ml})$, water absorption capacity (2.98m/g), least gelation concentration $(4.4 \mathrm{~g} / \mathrm{g})$, oil absorption capacity $(0.71 \mathrm{~m} / \mathrm{g})$, while control had the highest swelling capacity $(1.68 \mathrm{~g} / \mathrm{g})$. Significant differences at $p<0.05$ were found on the pasting properties of addition of hydrocolloids with lower pasting temperature ( $\left.71^{\circ} \mathrm{C}\right)$ and time (6.08 min). Bread quality attributes such as loaf volume, specific loaf volume, oven spring, crust colour, crumb colour and firmness of the fresh breads significantly improved with the addition of hydrocolloids compared with bread produced without improvers. The results show that high quality cassava flour could be incorporated up to $18 \%$ with carboxymethylcellulose at $2 \%$ level without affecting its overall acceptability and thereby enhance the potential for using locally produced flours in bread baking. Sensory score of bread from the addition of hydrocolloids were all acceptable by the panelist. The addition of hydrocolloids could be used as an effective means of improving the quality of gluten free bread.
\end{abstract}

Keywords: bread, carboxymethylcellulose, hydrocolloid, guargum, high quality cassava flour

\section{Introduction}

Bakery products are important ready-to-eat processed foods. Bread, sweet-dough products, biscuits, cookies, crackers and cakes are common bakery products that are consumed widely across the world. Bakery products nowadays have become essential and significant components of the dietary profile of the population. Bread may be described as a fermented bakery product which is produced mainly from wheat flour, yeast, water, sugar, salt and other ingredients needed accordingly, by a series of processes involving mixing, kneading, proofing, shaping, baking (Dewettinck et al., 2008). The incidence of celiac disease, which is a gluten intolerance disease, has made researcher in across the globe to search for gluten-free flours instead of wheat flour for bread making (Belc \& Biliaderis, 2007). Wheat is the most extensively grown cereal crop in the world, covering about 237 million hectares annually, accounting for a total of 420 million tonnes (Isitor et al., 1990, Langer et al 1991, Olabanji et al., 2004), and for at least one-fifth of man's calorie intake (Ohiagu et al., 1987). It is grown all over the world for its highly nutritious and useful grain, as one of the top three most produced crops, along with corn and rice. However, in the developing countries such as in the sub-Saharan Africa, research efforts are devoted to partial substitution of wheat flour for bread baking purposes, in order to reduce the huge expenditure on wheat importation and to increase the utilization of locally available food crops. Improvement of wheat-less bread quality could be promoted by addition of different kinds of additives, especially hydrocolloids. However, cassava contains no gluten, and partial substitution of wheat flour therefore impairs the quality of the bread. This effect has been attributed to reduced flour strength and gas retention capacity due to the lack of gluten proteins, thereby reducing bread volume and the sensory appeal of most baked composite bread (FAO, 2013). To counteract these technological problems, several improvers have been used to mimic gluten properties. Hydrocolloids are high molecular and hydrophilic biopolymers which have found a wide application as additives in baked product manufacture in the food industry. The most significant features are their ability to control the rheological properties or modify dough rheology and keeping qualities of finished baked product (Toufeili et al., 1994). In baking industry, they are added to stabilize emulsions, suspensions and foams and to improve the processing properties. Among other properties they have the ability to inhibit starch retrogradation, retain moisture, improve the overall structure, used as substitute for fat and egg and slow down aging of products (Rodge et al., 2012, Sedivy et al., 2013, Eduardo et al. 2014, Qiu et al., 2015). An important positive feature is the use of hydrocolloids in small quantities $(<1 \%)$ has a significant impact on enhanced ability of dough to bind water, increase the volume of products, slow retrogradation of starch and thus extend the shelf life of bakery products (Skara et al., 2013). It was found that the effect of the different types of hydrocolloids varied and a concentration of $0.1 \%$ was enough to cause the observed effects. Although, it has been reported in previous studies that substitution of wheat flour up to about $20 \%$ level is possible to give acceptable composite bread loaf (Hsu et al., 2004), however increasing substitution of wheat with other flours progressively reduced the quality of bread which has been attributed to reduced flour strength and gas retention capacity due to reducing gluten content, thereby reducing bread volume 
and the sensory appeal of most baked composite bread. However, little attention is paid to quality impairment of composite bread viz-a-viz fresh and keeping quality of composite bread. Although the improving effects of hydrocolloids in baking have been studied, there is scarce information about the combined effects of hydrocolloids on the quality of composite breads containing high quality cassava flours and there is need to provide wholesome for growing Nigerian population. Hence, this study was carried out to improve the baking quality of composite bread in a study of the effects of an addition of two hydrocolloids and high quality cassava flour on functional, color, pasting and physical (loaf volume, specific volume, density and moisture content) of composite wheat-high quality cassava bread.

\section{Materials and Methods}

\section{Materials}

The materials used were Dangote wheat flour, sugar, salt, margarine and yeast which were produced from a local market in Lagos state, Nigeria. High quality cassava flour were purchased from Federal University of Agriculture, Abeokuta Ogun State, Nigeria Carboxylmethylcellulose and guargum were purchased from Mekang Resources and Allied Distribution Ltd., Lagos State, Niger

\section{Production of bread}

A bread recipe, based on flour weight, consisting of $500 \mathrm{~g}$ of flour (high quality cassava $30 \%$, and wheat $70 \%$ ), $1.6 \%$ dry yeast, $1.5 \%$ salt, $3 \%$ vegetable oil from soybeans, 1 to $3 \%$ hydrocolloids and $88.3 \%$ water, was used in this study. The bread processing followed a planned design presented in Table 1 and straight dough method described by Eggleston et al. (1993) was followed. The ingredients were mixed for $10 \mathrm{~min}$ in a mixer (Kitchen Aid, KSM9, Michigan, USA), allowed to rest at room temperature for $45 \mathrm{~min}$, divided into $50 \mathrm{~g}$ each, hand molded, and placed into bread pans. Dough was proofed at $30^{\circ} \mathrm{C}$ and $80 \%$ relative humidity for $45 \mathrm{~min}$. The loaves were baked at $220^{\circ} \mathrm{C}$ for $10 \mathrm{~min}$ in a convection oven (Dahlen S400, Sveba Dahlen AB, Sweden). After baking, the loaves were removed from the pans and allowed to rest for cooling for $60 \mathrm{~min}$ at ambient conditions before weighing. A $100 \%$ wheat bread sample with no hydrocolloids and high quality cassava flour was used as a control. Cooled bread samples were packaged in polypropylene bags to prevent moisture loss and were used for further analysis.

Table 1. Dough formulation used for composite bread from wheat-HQCF blends

\begin{tabular}{|c|c|c|c|c|c|c|c|}
\hline Ingredients(g) & $\mathrm{T}_{0}$ & $\mathrm{~T}_{1}$ & $\mathrm{~T}_{2}$ & $\mathrm{~T}_{3}$ & $\mathrm{~T}_{4}$ & $\mathrm{~T}_{5}$ & $\mathrm{~T}_{6}$ \\
\hline Wheat flour \% & 100 & 90 & 90 & 80 & 80 & 70 & 70 \\
\hline HQCF \% & - & 9 & 9 & 18 & 18 & 27 & 27 \\
\hline Hydrocolloids \% & - & 1 & 1 & 2 & 2 & 3 & 3 \\
\hline Salt $\quad(\%)$ & 2 & 2 & 2 & 2 & 2 & 2 & 2 \\
\hline Sugar (\%) & 6 & 6 & 6 & 6 & 6 & 6 & 6 \\
\hline Yeast (\%) & 5 & 5 & 5 & 5 & 5 & 5 & 5 \\
\hline Fat (\%) & 3 & 3 & 3 & 3 & 3 & 3 & 3 \\
\hline EDC (\%) & 0.3 & 0.3 & 0.3 & 0.3 & 0.3 & 0.3 & 0.3 \\
\hline Water & 186 & 186 & 186 & 186 & 186 & 186 & 186 \\
\hline
\end{tabular}

Source: Modified method of Shittu et al. (2007). \% values are based on the total flour weight (300g) Values in parenthesis denotes percentage ingredient

\section{Determination of functional properties of composite flour}

Bulk density of the sample was determined using the method described by Akpapunarn and Markakis (1981). Water absorption capacity of the sample was determined using the method described by Sosulski et al., (1976). The water absorption capacity was expressed as volume of water absorbed per gram of flour. Swelling power of the flour blend was determined using the method described Okaka and Potter (1977). The method of Nwosu et al., (2010) was used to determine oil absorption capacity. Least gelation concentration was determined according to the method described by Coffman and Garcia (1977). Pasting properties of the flour was determined using Rapid Visco Analyser (RVA TECMASTER, Perten Instrument, Kungens Kurva, Sweden) as described by Sanni et al.(2004).

\section{Physical characteristics of bread}

Physical properties of the bread loaves, weight, length, height, breadth and volume of the loaves produced after baking was measured $1 \mathrm{~h}$ after removal of the loaves from the oven. Loaf weight was measured 30 min after baking as described by Giami et al., (2004), Oven spring was estimated from the difference in height of dough before and after baking. Loaf volume was measured using the rapeseed displacement method as modified by Giami et al. (2004). Specific loaf volume ( $\left.\mathrm{cm}^{3} / \mathrm{g}\right)$ was determined by the described by Araki et al. (2009). 


\section{Determination of crust colour}

The colour of the bread crust and crumb were measured 180 min after baking in four loaves. Crust colour was quantified with the digital colour imagine system (DigiEye) (Cromocol Scandinavia AB, Boras, Sweden). The controlled illumination cabinet on the DigiEye equipment was utilized to capture high resolution images of the fresh bread surface. The DigiEye 2.53b software (Cromocol Scandinavia AB, Boras, Sweden) allows for storage of specific colour standards with a given $L^{*}$ (lightness), $\mathrm{a}^{*}$ (redness-greenness), and $\mathrm{b}^{*}$ (yellowness-blueness) values according to the CIELAB definition. The results were reported as brownness index (BI), calculated according to Maskan, 2001.

$$
\mathrm{BI}=\frac{[100(\mathrm{X}-0.31)]}{0.17}
$$

where:

$$
\begin{aligned}
& x=\frac{a+1.75 \mathrm{~L}}{5.645 \mathrm{~L}+\mathrm{a}-3.01 \mathrm{~b}} \\
& \text { Determination of crumb firmness }
\end{aligned}
$$

The crumb firmness was measured $6 \mathrm{hr}$ after baking, using Instron universal testing machine (UTM, model 5542). The AACC standard method 74-09 was used. The measurements were carried out on $25 \mathrm{~mm}$ - thick slices taken from the center part of the loaf of the bread. Samples were compressed to approximately $10 \mathrm{~mm}$ ( $40 \%$ of the thickness of the slice) at a test speed of $1.7 \mathrm{~mm} / \mathrm{sec}$. The measurements were carried out on four loaves from each batch, and the compression force (in Newton). At the end, the compression was defined as firmness.

\section{Sensory evaluation of bread samples}

The sensory analysis was carried out using 25 untrained panelist selected from Department of Food Technology, Yaba College of Technology as described by Julianti et al.(2015). Bread samples were coded and scored on a 9-point hedonic scale and cut into slices and served randomly. Water was provided to wash palate in between tasting. All the bread samples were analyzed on a scale ranged from $9=$ like extremely to $1=$ dislike extremely for attributes such as appearance, taste, aroma, texture, and overall acceptability.

\section{Statistical Analysis}

Data collected were analyzed using IBM Statistical Package for the Social Sciences (SPSS) (2011). Analysis of variance (ANOVA) was used for determining significant differences $(p<0.05)$ and means were separated using the Duncan multiple Range Test.

\section{Results and discussion \\ Functional properties of flour blends}

The results of the functional properties of composite flour blends are presented in Table 2. Significant differences $(p<0.05)$ were found in the bulk density of all the composite flours. The bulk density ranges from 0.680 to $0.704 \mathrm{~g} / \mathrm{ml}$ with sample $\mathrm{T}_{5}$ having the highest bulk density while sample $T_{2}$ had the lowest bulk density value. Bulk density is a function of particle size as particle size is reported to be inversely proportional to bulk density and may have been responsible for the variation in the bulk densities of composite flour (Appiah et al., 2011). Bulk density of this study was however lower than that of control which may also indicate the requirement of larger storage area for wheat-high quality cassava flour blends. A decrease was observed in the bulk density as compared to what was reported by Ayo and Nkama (2004) but higher than bulk density reported by Mepba et al. (2007) which may be due to addition of high quality cassava flour reported by Adebowale et al., (2005). A decrease was observed in the bulk density as compared to what was reported by Ayo and Nkama, (2004) but higher than bulk density reported by Mepba et al. (2007) which may be due to addition of high quality cassava flour reported by Adebowale et al., (2005). The results of the bulk density obtained in this study were very low to the findings of Iwe et al., (2017). Water absorption capacity is important in the development of ready to eat foods, and it has been reported that high absorption capacity may encourage product cohesiveness (Houson and Ayenor, 2002). The water absorption capacityis an index of the ability of a product to associate with water under a condition where water is limiting (Omueti et al., 2009)

Table 2. Effect of hydrocolloid addition on functional properties of wheat-high quality cassava flour blends

\begin{tabular}{cccccc}
\hline Samples & Bulk density $(\mathrm{g} / \mathrm{ml})$ & WAC $(\mathrm{ml} / \mathrm{g})$ & LGC $(\mathrm{g} / \mathrm{g})$ & $\begin{array}{c}\text { swelling } \\
\text { power }(\mathrm{g} / \mathrm{g})\end{array}$ & OAC(ml/g) \\
\hline $\mathrm{T}_{0}$ & $0.680 \pm 0.00^{\mathrm{a}}$ & $2.04 \pm 0.01^{\mathrm{d}}$ & $4.07 \pm 0.01^{\mathrm{f}}$ & $1.68 \pm 0.01^{\mathrm{a}}$ & $0.30 \pm 0.01^{\mathrm{a}}$ \\
$\mathrm{T}_{1}$ & $0.698 \pm 0.00^{\mathrm{b}}$ & $2.36 \pm 0.00^{\mathrm{b}}$ & $3.76 \pm 0.01^{\mathrm{c}}$ & $1.51 \pm 0.01^{\mathrm{a}}$ & $0.59 \pm 0.01^{\mathrm{c}}$ \\
$\mathrm{T}_{2}$ & $0.699 \pm 0.00^{\mathrm{bc}}$ & $2.19 \pm 0.01^{\mathrm{c}}$ & $3.94 \pm 0.02^{\mathrm{e}}$ & $1.60 \pm 0.01^{\mathrm{bc}}$ & $0.70 \pm 0.01^{\mathrm{d}}$ \\
$\mathrm{T}_{3}$ & $0.701 \pm 0.00^{\mathrm{d}}$ & $2.20 \pm 0.71^{\mathrm{c}}$ & $3.41 \pm 0.01^{\mathrm{b}}$ & $1.50 \pm 0.00^{\mathrm{e}}$ & $0.51 \pm 0.01^{\mathrm{b}}$ \\
$\mathrm{T}_{4}$ & $0.702 \pm 0.00^{\mathrm{c}}$ & $2.25 \pm 0.01^{\mathrm{bc}}$ & $3.86 \pm 0.01^{\mathrm{d}}$ & $1.58 \pm 0.01^{\mathrm{d}}$ & $0.61 \pm 0.01^{\mathrm{c}}$ \\
$\mathrm{T}_{5}$ & $0.704 \pm 0.00^{\mathrm{f}}$ & $2.95 \pm 0.02^{\mathrm{a}}$ & $4.38 \pm 0.01^{\mathrm{a}}$ & $1.62 \pm 0.01^{\mathrm{b}}$ & $0.71 \pm 0.01^{\mathrm{d}}$ \\
$\mathrm{T}_{6}$ & $0.699 \pm 0.00^{\mathrm{c}}$ & $2.98 \pm 0.01^{\mathrm{a}}$ & $4.44 \pm 0.01^{\mathrm{g}}$ & $1.65 \pm 0.01^{\mathrm{ab}}$ & $0.68 \pm 0.01^{\mathrm{a}}$
\end{tabular}

Values are mean and standard deviations of three determinations. Values with different superscripts within the same row are significantly different $(p<0.05)$. 
Water absorption capacity ranges between 2.04 to $2.98 \mathrm{~g} / \mathrm{g}$ with sample $\mathrm{T}_{0}$ having the lowest while sample $\mathrm{T}_{6}$ had the highest. High water absorption capacity is attributed to loosed structure of the starch polymers while low value indicates the compactness of the molecular structure and also probably because guargum is polysaccharides based compound and basically hydrophilic. Selomulyo and Zhou, (2007) reported that the addition of hydrocolloid increases water absorption capacity of the dough. The result of this study suggests that the effect of hydrocolloids on wheat and high quality cassava flour could be useful in foods systems which require hydration to improve handling features (Akubor et al., 2013). Therefore, the result of water absorption capacity obtained in this study was in agreement with the findings of Iwe et al. (2017). Least gelation concentration (LGC) which is a measure of the minimum amount of flour or blends of flour that is needed to form a gel in a measured volume of water. It ranges from 3.41 to $4.44 \%$ with sample $\mathrm{T}_{6}$ had the highest value while sample $\mathrm{T}_{5}$ had the lowest. Swelling index is the capability to absorb water and increase in volume. It directly affects the dough and baking properties. Swelling index of composite flour was lower than that of control which might be the reason behind poor baking performance of composite flour. The swelling capacity ranges from 1.51 to $1.68 \mathrm{~g} / \mathrm{g}$ with sample $\mathrm{T}_{0}$ having the highest swelling capacity while sample $T_{2}$ had the lowest. Oil absorption capacity ranged between 0.30 and $0.71 \mathrm{ml} / \mathrm{g}$. Oil absorption capacity is an important property in food formulations because fat improves the flavour and mouth-feel of foods
(Kinsella, 1976). The lower oil absorption capacity of composite flour obtained in this study might be due to low hydrophobic proteinnwhich shows superior binding of lipids. The result of the oil absorption capacity obtained in this study was very low to the findings of (Nwosu et al. 2017).

\section{Pasting properties of hydrocolloids addition on wheat and HQCF blends}

Table 3 shows the effect of hydrocolloids addition on the pasting properties of wheat and high quality cassava flour blends. When a starchbased foods are heated in an aqueous environment, they undergo series of changes known as gelatinization and pasting. These two important properties are known to influence the quality and aesthetic considerations in the food industry, since they affect texture, digestibility and the end use of starchy foods (Adebowale et al., 2005). Peak viscosity indicate the ability of starch to swell freely before their physical breakdown (Sanni et al., 2004) ranged from 2341.0 to 3491.0 RVU. Wheat flour substituted with high quality cassava flour at $9 \%$ with guargum at $1 \%$ recorded the highest value of 3491.0 RVU. High peak viscosity is an indication of high starch content (Osungbaro, 1990). It is also related to the water binding capacity of starch or mixture in a product which also correlates with final product quality and also provides an indication of the viscous load likely to be encountered by the mixing heating cooker (Adebowale et al., 2005).

Table 3. Effect of hydrocolloids addition on the pasting properties of wheat and HQCF blends

\begin{tabular}{cccccccc}
\hline Samples & $\mathrm{T}_{0}$ & $\mathrm{~T}_{1}$ & $\mathrm{~T}_{2}$ & $\mathrm{~T}_{3}$ & $\mathrm{~T}_{4}$ & $\mathrm{~T}_{5}$ & $\mathrm{~T}_{6}$ \\
\hline Peak viscosity & $2459 \pm 1.41^{\mathrm{c}}$ & $2341 \pm 1.41^{\mathrm{a}}$ & $3491 \pm 1.41^{\mathrm{g}}$ & $2385 \pm 0.71^{\mathrm{b}}$ & $2889 \pm 1.41^{\mathrm{d}}$ & $3041 \pm 0.71^{\mathrm{e}}$ & $3453 \pm 1.41^{\mathrm{f}}$ \\
Trough & $1568 \pm 0.70^{\mathrm{b}}$ & $1609 \pm 0.71^{\mathrm{c}}$ & $2679 \pm 0.71^{\mathrm{g}}$ & $1534 \pm 0.71^{\mathrm{a}}$ & $1993 \pm 1.41^{\mathrm{d}}$ & $2205 \pm 4.95^{\mathrm{f}}$ & $2175 \pm 0.71^{\mathrm{e}}$ \\
Breakdown & $891 \pm 0.71^{\mathrm{e}}$ & $734 \pm 1.41^{\mathrm{a}}$ & $814 \pm 0.71^{\mathrm{b}}$ & $849 \pm 1.41^{\mathrm{d}}$ & $897 \pm 1.41^{\mathrm{f}}$ & $841 \pm 1.41^{\mathrm{c}}$ & $1280 \pm 0.71^{\mathrm{g}}$ \\
Final viscosity & $3262 \pm 2.12^{\mathrm{c}}$ & $2595 \pm 7.07^{\mathrm{a}}$ & $4067 \pm 0.71^{\mathrm{g}}$ & $2841 \pm 1.41^{\mathrm{b}}$ & $3345 \pm 1.41^{\mathrm{d}}$ & $3586 \pm 0.71^{\mathrm{f}}$ & $3551 \pm 1.41^{\mathrm{e}}$ \\
Setback & $1696 \pm 0.71^{\mathrm{g}}$ & $992 \pm 1.41^{\mathrm{a}}$ & $1389 \pm 1.41^{\mathrm{f}}$ & $1309 \pm 1.41^{\mathrm{b}}$ & $1351 \pm 1.41^{\mathrm{c}}$ & $1386 \pm 1.41^{\mathrm{e}}$ & $1377 \pm 0.71^{\mathrm{d}}$ \\
Pasting time (min) & $6.32 \pm 0.01^{\mathrm{c}}$ & $6.48 \pm 0.01^{\mathrm{d}}$ & $6.24 \pm 0.01^{\mathrm{f}}$ & $6.28 \pm 0.01^{\mathrm{b}}$ & $6.54 \pm 0.01^{\mathrm{e}}$ & $6.34 \pm 0.01^{\mathrm{c}}$ & $6.08 \pm 0.01^{\mathrm{a}}$ \\
Pasting Temp. $\left({ }^{\circ} \mathrm{C}\right)$ & $73 \pm 0.01^{\mathrm{b}}$ & $73 \pm 0.01^{\mathrm{e}}$ & $72 \pm 0.01^{\mathrm{c}}$ & $72 \pm 0.01^{\mathrm{f}}$ & $72 \pm 0.01^{\mathrm{d}}$ & $71 \pm 0.01^{\mathrm{a}}$ & $71 \pm 0.01^{\mathrm{c}}$ \\
\hline
\end{tabular}

Values are mean and standard deviations of three determinations. Values with different superscripts within the same row are significantly different $(p<0.05)$.

The increase in peak viscosity of the composite flour may be attributed to the increased in the percentage of high quality cassava flour which has been subjected to drying which allows for more starch degradation or de-branching to simpler units which is an indication of starch structural damage. Trough (holding strength) is the maximum viscosity value in the constant temperature phase of the RVA profile and measures the ability of paste to withstand breakdown during cooling, trough ranged between 1533.5 and 2678.5 RVU. Wheat flour substituted with high quality cassava flour at $9 \%$ with guargum at $1 \%$ had the highest value for trough while wheat flour substituted with high quality cassava flour at $18 \%$ with carboxymethylcellulose at $2 \%$ had the lowest value for trough. Sample $\mathrm{T}_{2}$ will withstand breakdown during cooling than other composite samples. The decrease in trough viscosity with in high quality cassava flour and hydrocolloids may be attributed to starch degradation during which caused a decrease in viscosity value. The breakdown viscosity value is an index of the stability of starch (Fernande et al., 1989); and a measure of the ease with which the swollen granules can be disintegrated. Cohesiveness of paste is attributed to the extent of breakdown of starch molecules during heating and stirring. The value for the breakdown viscosity ranged between 734.0 and 1279.5 RVU with wheat flour substituted with high quality cassava flour at $9 \%$ with carboxymethylcellulose at $1 \%$ had the lowest value for breakdown while wheat flour substituted with high quality cassava flour at $27 \%$ with guargum at $3 \%$ had the highest value for breakdown. Breakdown viscosity can also known as shear thinning, hot paste viscosity, paste stability and is regarded as a measure of the degree of disintegration of the granules (Bakare, 2012). Final viscosity is the viscosity at the end of the rest which is the change in the viscosity after holding cooked starch at $50{ }^{\circ} \mathrm{C}$ ranged from 2595.0 to 4066.5 RVA. Final viscosity is the most commonly used parameter to define the quality of a particular starch-based sample as it indicates the ability of the material to form a viscous paste or gel after cooking and cooling as well as the resistance of the paste to shear force during stirring (Adeyemi and Idowu, 1990). Setback viscosity ranged from 992.0 to 1695.5RVU. Significant differences $(\mathrm{p}<0.05)$ were observed in the setback viscosity of wheat and high quality cassava flour. The higher the setback, the lower the retrogradation of the flour paste during cooling and the lower the staling rate of the product made from the flour (Adeyemi and Idowu, 1990). Setback viscosity is measured as the difference between the final viscosity and the trough. It is the phase of the pasting curve after cooling the starch to $50{ }^{\circ} \mathrm{C}$. It is a stage that involves re-association, retrogradation or re-ordering of starch molecules. It shows the tendency of starch to associate and retrograde. 
Setback value has been reported to correlate with the texture of various food products (Mikhiyo et al., 2004). Peak time is known a measure of the cooking time or the time at which the peak viscosity occurred in minutes which is an indication of the ease of cooking the starch product. Peak time ranged between 6.08 to 6.74 min with wheat flour substituted with high quality cassava flour at $9 \%$ with guargum at $1 \%$ having the highest value of $6.74 \mathrm{~min}$ and wheat flour substituted with high quality cassava flour at $27 \%$ with guargum at $3 \%$ having the lowest peak time of $6.08 \mathrm{~min}$. There were significant difference $(\mathrm{p}<0.05)$ in the peak time among the blends. The pasting temperature ranged between $71{ }^{\circ} \mathrm{C}$ and $72.60{ }^{\circ} \mathrm{C}$. It was observed that there was significant differences $(\mathrm{p}<0.05)$ in pasting temperature among all the samples. The pasting temperature provides an indication of minimum temperature required for cooking the samples, the pasting temperature obtained for the composite flours were quite close.

\section{Effect of hydrocolloid addition on the physical properties of wheat and HQCF bread}

Table 4 shows the effect of hydrocolloids on the physical properties of wheat and high quality cassava bread. Significant differences $(p<0.05)$ exist in the physical attributes that were measured The loaf weight of the bread ranges from 169.5 to $191.5 \mathrm{~g}$ with bread produced from wheat flour substituted with HQCF at 27\% and carboxymethylcellulose at 3\% having the lowest loaf weight while bread produced from wheat flour substituted with HQCF at $18 \%$ and carboxymethylcellulose at $2 \%$ having the highest loaf weight. There was variation in the loaf weight of the bread which can be attributed to lower level of gluten network in the dough which consequently affects the ability for the dough to rise (Shittu et al., 2006). Higher loaf weights have positive economic effect on bread at the retail end. Therefore, loaf weight reduction during baking is an undesirable economic quality to the bakers as consumers often get attracted to bread loaf with higher weight and volume believing that it has more substance for the same price (Shittu et al., 2006). The result of the loaf weight obtained in this study was higher than the findings of Edwardo et al. (2016). Loaf volume is regarded as one of the most important baked good characteristics, since it provides a qualitative measurement of baking performance (Kohajdora and Karovicova, 2008).

Table 4. Effect of hydrocolloid addition on the physical properties of wheat and HQCF bread

\begin{tabular}{|c|c|c|c|c|c|c|c|c|}
\hline Samples & Length & Breadth & Height & $\begin{array}{l}\text { Weight } \\
\text { (g) }\end{array}$ & $\begin{array}{r}\text { Volume } \\
\left(\mathrm{cm}^{3}\right)\end{array}$ & $\begin{array}{c}\text { Specific } \\
\text { volume }\left(\mathrm{cm}^{3} / \mathrm{g}\right)\end{array}$ & $\begin{array}{l}\text { Oven } \\
\text { spring }\end{array}$ & $\begin{array}{l}\text { Loaf } \\
\text { density } \\
\mathrm{g} / \mathrm{cm}^{3}\end{array}$ \\
\hline $\mathrm{T}_{0}$ & $14.7 \pm 0.14^{\mathrm{a}}$ & $8.6 \pm 0.01^{\mathrm{c}}$ & $8.5 \pm 0.01^{\mathrm{f}}$ & $171.5 \pm 0.71^{\mathrm{b}}$ & $1074.57 \pm 0.01^{\mathrm{f}}$ & 6.27 & 2.1 & 0.16 \\
\hline $\mathrm{T}_{1}$ & $14.9 \pm 0.01^{\mathrm{b}}$ & $8.6 \pm 0.01^{\mathrm{c}}$ & $8.5 \pm 0.00^{\mathrm{f}}$ & $177.5 \pm 0.71^{\mathrm{c}}$ & $1089.2 \pm 0.00^{\mathrm{g}}$ & 6.14 & 1.1 & 0.16 \\
\hline $\mathrm{T}_{2}$ & $14.6 \pm 0.01^{\mathrm{a}}$ & $8.7 \pm 0.01^{\mathrm{c}}$ & $6.1 \pm 0.04^{\mathrm{c}}$ & $177.5 \pm 0.71^{\mathrm{c}}$ & $724.8 \pm 0.00^{\mathrm{c}}$ & 4.08 & 1.2 & 0.25 \\
\hline $\mathrm{T}_{3}$ & $14.9 \pm 0.14^{\mathrm{a}}$ & $8.3 \pm 0.02^{\mathrm{a}}$ & $5.7 \pm 0.01^{\mathrm{b}}$ & $191.5 \pm 0.71^{\mathrm{e}}$ & $709.7 \pm 0.01^{b}$ & 3.71 & 1.5 & 0.27 \\
\hline $\mathrm{T}_{4}$ & $14.9 \pm 0.07^{\mathrm{b}}$ & $8.5 \pm 0.01^{\mathrm{b}}$ & $7.5 \pm 0.01^{\mathrm{e}}$ & $183.5 \pm 0.71^{\mathrm{d}}$ & $956.2 \pm 0.01^{\mathrm{e}}$ & 5.21 & 1.5 & 0.19 \\
\hline $\mathrm{T}_{5}$ & $14.6 \pm 0.01^{\mathrm{a}}$ & $8.6 \pm 0.00^{c}$ & $5.2 \pm 0.01^{\mathrm{a}}$ & $169.5 \pm 0.71^{\mathrm{a}}$ & $652.9 \pm 0.00^{\mathrm{a}}$ & 3.85 & 1.8 & 0.26 \\
\hline $\mathrm{T}_{6}$ & $14.9 \pm 0.07^{\mathrm{b}}$ & $8.6 \pm 0.01^{\mathrm{c}}$ & $6.5 \pm 0.01^{\mathrm{d}}$ & $172.0 \pm 1.41^{\mathrm{b}}$ & $832.9 \pm 0.01^{\mathrm{d}}$ & 4.84 & 1.7 & 0.21 \\
\hline
\end{tabular}

Mean values with different superscripts within the same column are significantly different $(p<0.05)$

The loaf volume of bread produced wheat and HQCF ranges from 652.9 to $1089.2 \mathrm{~cm}^{3}$ with bread produced from wheat flour substituted with $\mathrm{HQCF}$ at $9 \%$ and carboxymethylcellulose at $1 \%$ from having the highest loaf volume while bread produced from wheat flour substituted with HQCF at $27 \%$ and carboxymethylcellulose at $3 \%$ had the lowest loaf weight. Generally, there was a reduction in the loaf weight of wheatHQCF bread; the reduction in volume could be attributed to poor gas retention which was an indication of the low gluten content of that has weakened the flour due to the addition of HQCF and hydrocolloid. Oven spring, which takes place in the early period of baking, is a measure of dough strength or stability that is basically dependent on certain factors such as thermal regime (heating rate and duration), type of flour and ingredients used in dough formulation (Rao and Hemamalini, 1991). The oven spring was highest in control bread sample. On the other hand, the less oven spring, loaf volume and specific volume of the composite breads resulted from lower gluten fraction is responsible for the elasticity of the dough by causing it to extend and trap the carbon dioxide generated by yeast during fermentation. When gluten coagulates under the influence of heat during baking, it serves as the framework of the loaf, which becomes relatively rigid and does not collapse. Similarly, the adverse effects of addition of fibre on dough structure and loaf volume have been suggested to be due to the dilution of gluten network, which in turn impairs gas retention rather than gas production (Elleuch et al.,
2011). In addition, polymeric changes such as starch gelatinization and protein denaturation which take place in the oven affect dough viscosity and further determine the amount of stress exerted by gas on the cell wall (Blanshard, 1987). Furthermore, excessive stress on the gas cell could lead to tensile failure and opening up of the cell wall faces (Fan et al., 1999), thereby leading to gas cell coalescence or dough collapse as observed in 3\% substitution with hydrocolloids and HQCF. The result of the loaf volume obtained in this study was not in agreement with the findings of Fan et al., (1999). The result of some physical property of the bread loaf shows that addition of guargum up to $3 \%$ concentration led to significant increase in oven spring and specific volume. The addition of guargum could have increase dough viscosity thereby imparting greater stability of the gluten-starch network in the composite dough during baking. This is in agreement with the observation of Shittu et al., (2009) who reported similar result on xanthan gum addition on composite cassava-wheat dough bread.

\section{Colour characteristics of composite bread from wheat- HQCF-hydrocolloids}

Colour is an important criterion for the acceptability of the baked product by the consumer. Moreover, as the development of colour occurs classically during the later stages of baking, it can be used to 
judge completion of the baking process. Surface colour depends both on the physico-chemical characteristics of the raw dough such as water content, $\mathrm{pH}$, reducing sugars. Table 7 shows the effect of hydrocolloids on crumb and crust colour of wheat and HQCF. Significant $(p<0.05)$ differences existed in lightness $\left(\mathrm{L}^{*}\right)$, redness $\left(\mathrm{a}^{*}\right)$, yellowness $\left(\mathrm{b}^{*}\right)$ of the crust and crumb colour of the bread. The crust lightness values range from 45.08 to 59.29 , redness ranges from 9.29 to 10.88 and yellowness ranges from 20.79 to 27.82 . The crust colour of the composite bread with hydrocolloids was significantly whiter but more red than wheat flour as shown in the positive value of $b^{*}$ while crumb colour for the composite bread was also significantly whiter but less red as shown in the negative value of $b^{*}$. Bread crust color is an important sensory attribute which can enhance acceptability. The local population thinks that pale colored bread crust is indicative of improper baking. Moreover, it is assumed that the brown color is what impacts nutrient, especially, iron on the product. Lightness showed a significant increase $(\mathrm{p}<0.05)$ in $L^{*}$ value with increasing level of hydrocolloid and HQCF. Lower $L^{*}$ value indicates darker crumb, $a^{*}$ positive value is associated with crumb redness, whereas $b^{*}$ positive value indicates yellow colour. This increase in lightness could be due to decrease in protein content of composite breads which can affect the Maillard reaction in the crust of bread. The crust characteristic is known to be associated with Maillard reaction, thus containing more protein can increase the Maillard reaction and browner color. The result indicates the browning effect which is in agreement with values reported by Jusoh et al. (2012). The crust colour of bread produced from wheat and HQCF was brown and this might be attributed to Millard browning reaction caused between the reducing sugar and proteins (Fayle and Gerard, 2002). Significant $(\mathrm{p}<0.05)$ differences existed in lightness, redness, yellowness of the crumb colour of the bread produced from wheat and HQCF. The crumb lightness values range from 74.13 to 77.93 , redness ranges from -0.36 to -0.77 and yellowness ranges from 10.85 to 12.80 . Bread produced from wheat flour substituted with $\mathrm{HQCF}$ at $9 \%$ and carboxymethylcellulose at $1 \%$ had the highest lightness and redness while bread produced from wheat flour substituted with $\mathrm{HQCF}$ at $9 \%$ and guargum at $1 \%$ had the highest yellowness. Color is also an inevitable check that could be used in determining the effects of ingredients or product formulation, process variable as well as the storage condition on baked products (Jusoh et al., 2012).

Table 5. Effect of hydrocolloids addition on bread crust and crumb colour of composite bread

\begin{tabular}{|c|c|c|c|c|c|c|}
\hline Samples & $\begin{array}{c}\text { crust } \\
\text { lightness }\left(L^{*}\right)\end{array}$ & $\begin{array}{c}\text { crust } \\
\text { redness }\left(\mathrm{a}^{*}\right)\end{array}$ & $\begin{array}{c}\text { crust } \\
\text { yellowness }\left(b^{*}\right)\end{array}$ & $\begin{array}{c}\text { crumb } \\
\text { lightness }\left(L^{*}\right)\end{array}$ & $\begin{array}{c}\text { crumb } \\
\text { redness }\left(\mathrm{a}^{*}\right)\end{array}$ & $\begin{array}{c}\text { crumb yellowness } \\
\left(\mathrm{b}^{*}\right)\end{array}$ \\
\hline $\mathrm{T}_{0}$ & $45.08 \pm 11.0^{\mathrm{a}}$ & $9.29 \pm 1.82^{\mathrm{a}}$ & $20.79 \pm 5.54^{\mathrm{a}}$ & $74.13 \pm 0.53^{\mathrm{a}}$ & $-0.74 \pm 0.04^{\mathrm{a}}$ & $11.86 \pm 0.13^{\mathrm{c}}$ \\
\hline $\mathrm{T}_{1}$ & $55.57 \pm 1.19^{\mathrm{ab}}$ & $10.04 \pm 0.11^{\mathrm{a}}$ & $25.97 \pm 0.71^{\mathrm{ab}}$ & $77.93 \pm 0.43^{c}$ & $-0.77 \pm 0.02^{\mathrm{a}}$ & $12.17 \pm 0.04^{\mathrm{d}}$ \\
\hline $\mathrm{T}_{2}$ & $51.56 \pm 0.88^{\mathrm{ab}}$ & $11.90 \pm 0.14^{\mathrm{b}}$ & $25.41 \pm 0.29^{\mathrm{ab}}$ & $74.36 \pm 0.32^{\mathrm{a}}$ & $-0.36 \pm 0.04^{c}$ & $12.80 \pm 0.25^{\mathrm{e}}$ \\
\hline $\mathrm{T}_{3}$ & $53.85 \pm 0.78^{\mathrm{ab}}$ & $11.95 \pm 0.60^{\mathrm{b}}$ & $26.56 \pm 0.53^{\mathrm{b}}$ & $76.56 \pm 0.67^{b}$ & $-0.38 \pm 0.01^{\mathrm{c}}$ & $12.40 \pm 0.03^{\mathrm{d}}$ \\
\hline $\mathrm{T}_{4}$ & $59.29 \pm 0.06^{\mathrm{b}}$ & $10.23 \pm 0.08^{\mathrm{ab}}$ & $27.82 \pm 0.01^{\mathrm{b}}$ & $77.42 \pm 0.71^{\mathrm{bc}}$ & $-0.61 \pm 0.04^{b}$ & $10.85 \pm 0.04^{\mathrm{a}}$ \\
\hline $\mathrm{T}_{5}$ & $54.05 \pm 0.15^{\mathrm{ab}}$ & $10.88 \pm 0.06^{\mathrm{ab}}$ & $26.80 \pm 0.13^{\mathrm{b}}$ & $76.97 \pm 0.03^{\mathrm{bc}}$ & $-0.66 \pm 0.02^{\mathrm{b}}$ & $11.52 \pm 0.12^{\mathrm{b}}$ \\
\hline $\mathrm{T}_{6}$ & $57.12 \pm 0.51^{\mathrm{b}}$ & $9.83 \pm 0.31^{\mathrm{a}}$ & $26.07 \pm 0.53^{\mathrm{ab}}$ & $74.67 \pm 0.23^{\mathrm{a}}$ & $-0.66 \pm 0.01^{\mathrm{b}}$ & $11.40 \pm 0.06^{\mathrm{b}}$ \\
\hline
\end{tabular}

Mean values with different superscripts within the same column are significantly different $(p<0.05)$.

\section{Textural properties of composite bread}

Table 6 shows the effect of hydrocolloids on textural properties of bread produced from wheat and high quality cassava flour. It is evident that all texture profile analysis parameters of the bread were significantly different $(p<0.05)$ from each other. The peak force is the force required to compress the material by a given amount (Abdelghafor et al., 2011). It can also be referred to as hardness of a product. The peak force of bread ranged from 226.5 to $619 \mathrm{~N}$. Bread produced from wheat flour substituted with high quality cassava flour at $18 \%$ and carboxymethylcellulose at $2 \%$ had the highest peak force (hardness) while bread produced from wheat flour substituted with high quality cassava flour at $9 \%$ and carboxymethylcellulose at $1 \%$ had the lowest peak force (hardness). Martin et al. (1991) reported that hardness of bread is caused by the formation of cross links between partially solubilized starch and gluten proteins. Resilience expresses the ability or speed material to return to its original shape after a stress. The resilience of bread produced from wheat and high quality cassava flour ranged from 0.10 to 0.30 . The value obtained for the resilience of the bread in this study was very low and this indicated the bread required more time to recover its shape. Gomez et al. (2013) reported that bread hardness was due to interactions between gluten and fibrous materials. According to a report by Hoseney et al., (1994) interaction between gelatinized starch and gluten dough which cause dough to be more elastic can form continuous sponge structure of bread after heating. Therefore, the high springiness in BC could be attributed to dilution of the gluten structure in composite breads. Lower amount of gluten cause lower ability to hold gases which caused an elasticity reduction in breads (Pyler, 1973). 
Table 6. Effect of hydrocolloid addition on the textural properties of composite bread

\begin{tabular}{cccccccc}
\hline Sample & $\mathrm{T}_{0}$ & $\mathrm{~T}_{1}$ & $\mathrm{~T}_{2}$ & $\mathrm{~T}_{3}$ & $\mathrm{~T}_{4}$ & $\mathrm{~T}_{5}$ & $\mathrm{~T}_{6}$ \\
\hline Peak force & $342.5 \pm 0.71^{\mathrm{c}}$ & $226.5 \pm 0.71^{\mathrm{a}}$ & $437.5 \pm 0.71^{\mathrm{e}}$ & $619.0 \pm 1.41^{\mathrm{g}}$ & $426.0 \pm 1.41^{\mathrm{d}}$ & $452.0 \pm 1.41^{\mathrm{f}}$ & $411.0 \pm 1.41^{\mathrm{b}}$ \\
Height & $48.76 \pm 0.02^{\mathrm{e}}$ & $48.95 \pm 0.07^{\mathrm{f}}$ & $45.95 \pm 0.07^{\mathrm{b}}$ & $46.31 \pm 0.01^{\mathrm{c}}$ & $47.47 \pm 0.01^{\mathrm{d}}$ & $45.11 \pm 0.01^{\mathrm{a}}$ & $45.18 \pm 0.01^{\mathrm{a}}$ \\
Weight & $58.50 \pm 0.71^{\mathrm{d}}$ & $51.75 \pm 0.01^{\mathrm{a}}$ & $49.50 \pm 0.71^{\mathrm{b}}$ & $52.00 \pm 1.41^{\mathrm{c}}$ & $52.00 \pm 1.41^{\mathrm{c}}$ & $51.50 \pm 0.71^{\mathrm{c}}$ & $49.50 \pm 0.71^{\mathrm{b}}$ \\
Resilience & $0.19 \pm 0.01^{\mathrm{b}}$ & $0.10 \pm 0.01^{\mathrm{a}}$ & $0.20 \pm 0.00^{\mathrm{a}}$ & $0.30 \pm 0.01^{\mathrm{c}}$ & $0.20 \pm 0.01^{\mathrm{b}}$ & $0.20 \pm 0.01^{\mathrm{b}}$ & $0.30 \pm 0.01^{\mathrm{c}}$ \\
Stickiness & $2.50 \pm 0.71^{\mathrm{a}}$ & $5.50 \pm 0.71^{\mathrm{b}}$ & $5.50 \pm 0.71^{\mathrm{b}}$ & $3.50 \pm 0.71^{\mathrm{a}}$ & $3.50 \pm 0.71^{\mathrm{a}}$ & $3.50 \pm 0.71^{\mathrm{a}}$ & $3.50 \pm 0.71^{\mathrm{a}}$ \\
Peak time & $9.77 \pm 0.00^{\mathrm{e}}$ & $9.75 \pm 0.01^{\mathrm{e}}$ & $9.12 \pm 0.01^{\mathrm{b}}$ & $9.33 \pm 0.04^{\mathrm{c}}$ & $9.56 \pm 0.01^{\mathrm{d}}$ & $9.03 \pm 0.01^{\mathrm{a}}$ & $9.00 \pm 0.01^{\mathrm{a}}$ \\
\hline
\end{tabular}

Values are mean and standard deviations of three determinations. Values with different superscripts within the same row are significantly different $(p<0.05)$.

\section{Consumer acceptability test of composite bread}

Sensory evaluation is usually performed towards the end of the product development or formulation cycle. It is carried out to assess the reaction of judges towards the product, and they rate the liking on a scale. Table 7 shows the sensory scores of bread produced from hydrocolloids addition on wheat and high quality cassava flour blends. Significant differences $(p<0.05)$ exist in all the sensory attributes measured for the bread except for texture and aroma. The score for appearance for the produced bread ranged from 6.50 to 7.85 . Bread produced from sample $T_{0}$ had the highest score for appearance (7.85) while bread produced from sample $\mathrm{T}_{2}$ had the lowest score for appearance (6.50). The taste score for all the bread samples ranged from 5.40 to 7.35 with bread sample $\mathrm{T}_{4}$ having the highest score for taste while bread sample $\mathrm{T}_{5}$ had the lowest score for taste. The hardness score for the bread samples ranged from 5.90 to 6.80 . Bread sample $T_{2}$ had the lowest score for hardness and bread sample $\mathrm{T}_{4}$ had the highest score for hardness. Hardness is mainly attributed to the amylose and amylopectin matrix which contributes to overall bread texture as bread hardness was due to interactions between gluten and fibrous materials. The score for mouth-feel ranged from 5.25 to 6.95 . Bread sample $T_{1}$ had the highest score for mouth-feel while bread sample $\mathrm{T}_{3}$ had the lowest score for mouth-feel. The aroma and flavour scores ranged from 5.80 to 6.70 and 5.45 to 7.15 respectively. Bread produced from sample $\mathrm{T}_{4}$ while bread sample $\mathrm{T}_{3}$ lowest score for aroma and flavour. The overall acceptability expresses how the consumers or panelists accept the product generally has ranges from 6.15 to 7.55 with bread sample $T_{3}$ having the highest overall acceptability while bread sample $\mathrm{T}_{4}$ had the lowest score. However, bread produced from wheat flour, high quality cassava and hydrocolloids were all accepted by the panelist, but bread produced from $100 \%$ wheat flour was the most preferred, this could be due to the familiarity of the consumers to the bread produced. Decrease in color scores was observed with increase in the level of replacement in composite flours (Ayo and Nkama, 2004). Generally, addition of hydrocolloids had significant effects on sensory attributes and overall acceptability of bread samples. Addition of guargum in different combinations for the preparation of bread showed a significant role towards the color of bread (Ayo and Nkama, 2004). Bread samples which received scores higher than 5 (neither like nor dislike) were considered as acceptable. Perceptions of flavor are a synthesis of taste and smell impressions, along with texture and are even influenced by appearance. The taste is a sensation perceived by the tongue and influenced by the texture, flavor and composition of the foods. The International Standards Organization defined texture of a food product as all the rheological and structural attributes of the product perceptible by means of mechanical, tactile, and where appropriate, visual and auditory receptors(ISO,1981). Food texture may be extremely important to the consumer. Yet, unlike color and flavor, texture is used by the consumer not as an indicator of food safety but as an indicator of food quality.

Table 7. Sensory scores of bread produced from wheat-HQCF-hydrocolloids

\begin{tabular}{|c|c|c|c|c|c|c|c|}
\hline Samples & Appearance & Taste & Hardness & Mouth-feel & Aroma & Flavour & $\begin{array}{c}\text { Overall } \\
\text { acceptability }\end{array}$ \\
\hline $\mathrm{T}_{0}$ & $7.85 \pm 0.88^{b}$ & $6.95 \pm 0.10^{\mathrm{b}}$ & $6.65 \pm 1.66^{\mathrm{a}}$ & $6.85 \pm 1.39^{b}$ & $6.35 \pm 1.73^{\mathrm{a}}$ & $6.50 \pm 1.64^{\mathrm{bc}}$ & $7.60 \pm 0.89^{c}$ \\
\hline $\mathrm{T}_{1}$ & $7.15 \pm 1.04^{\mathrm{ab}}$ & $6.90 \pm 1.11^{\mathrm{b}}$ & $6.55 \pm 1.28^{\mathrm{a}}$ & $6.95 \pm 1.28^{\mathrm{b}}$ & $6.40 \pm 1.50^{\mathrm{a}}$ & $6.60 \pm 1.31^{\mathrm{bc}}$ & $7.25 \pm 1.07^{\mathrm{bc}}$ \\
\hline $\mathrm{T}_{2}$ & $6.50 \pm 1.28^{\mathrm{a}}$ & $6.55 \pm 1.50^{\mathrm{ab}}$ & $5.90 \pm 1.48^{\mathrm{a}}$ & $6.20 \pm 1.44^{\mathrm{ab}}$ & $6.30 \pm 1.34^{\mathrm{a}}$ & $5.75 \pm 1.55^{\mathrm{ab}}$ & $6.45 \pm 1.10^{\mathrm{ab}}$ \\
\hline $\mathrm{T}_{3}$ & $6.90 \pm 1.25^{\mathrm{a}}$ & $5.40 \pm 2.04^{\mathrm{a}}$ & $6.20 \pm 1.44^{\mathrm{a}}$ & $5.25 \pm 2.14^{\mathrm{a}}$ & $5.80 \pm 1.85^{\mathrm{a}}$ & $5.45 \pm 2.09^{\mathrm{a}}$ & $6.15 \pm 2.06^{\mathrm{a}}$ \\
\hline $\mathrm{T}_{4}$ & $7.15 \pm 1.31^{\mathrm{ab}}$ & $7.35 \pm 1.57^{\mathrm{b}}$ & $6.80 \pm 1.28^{\mathrm{a}}$ & $6.80 \pm 1.32^{\mathrm{b}}$ & $6.70 \pm 0.92^{\mathrm{a}}$ & $7.15 \pm 1.22^{\mathrm{c}}$ & $7.55 \pm 1.35^{\mathrm{c}}$ \\
\hline $\mathrm{T}_{5}$ & $7.00 \pm 1.12^{\mathrm{a}}$ & $6.60 \pm 1.14^{\mathrm{b}}$ & $6.10 \pm 1.41^{\mathrm{a}}$ & $5.95 \pm 1.47^{\mathrm{ab}}$ & $6.35 \pm 1.09^{\mathrm{a}}$ & $6.30 \pm 0.98^{\mathrm{abc}}$ & $6.80 \pm 1.19^{\mathrm{abc}}$ \\
\hline $\mathrm{T}_{6}$ & $7.25 \pm 1.16^{\mathrm{ab}}$ & $6.45 \pm 1.50^{\mathrm{b}}$ & $6.70 \pm 1.38^{\mathrm{a}}$ & $6.25 \pm 1.52^{\mathrm{ab}}$ & $6.50 \pm 1.50^{\mathrm{a}}$ & $6.40 \pm 1.50^{\mathrm{abc}}$ & $7.20 \pm 1.20^{\mathrm{bc}}$ \\
\hline
\end{tabular}

Values are mean and standard deviations of three determinations. Values with different superscripts within the same row are significantly different $(p<0.05)$. 


\section{Conclusions}

The study shows that addition of guargum and carboxymethylcellulose had an improved effect on loaf volume, oven spring and specific volume of composite bread. Blending of hydrocolloid with wheat and high quality cassava flour had a significant effect on the functional and pasting properties. Addition of hydrocolloids affects the physical properties of the bread especially the loaf volume of the bread. However, high quality cassava flour could be incorporated up to $18 \%$ with carboxymethylcellulose at $2 \%$ level without affecting its overall acceptability. Further studies should be carried on the storage stability of effect of hydrocolloid on baking quality of wheat and high quality cassava bread and Community-based research trials are needed to demonstrate a significant health effect.

\section{References}

Abdelghafor R.F., Mustafa A.I., Ibrahim A.M.H., Krishnan P.G. (2011) Quality of Bread from Composite Flour of Sorghum and Hard White Winter Wheat. Advance Journal of Food Science and Technology 3(1) 9-15.

Adebowale AA., Sanni LO., Awonorin SO.(2005) Effect of texture modifies on the physiochemical and sensory properties of dried fufu. Journal of Food Science and Technology International, 11 373-385.

Adeyemi IA., Idowu MA. (1990) The Evaluation of Pregelatinized Maize Flour in the Development of Maissa, a Baked Product. Nigerian Food Journal 8 63-73.

Akpapunarn MA., Markakis D. (1981) Physico-chemical and nutritional aspects of cowpea flour. Journal of Food Science, $46972-973$.

Akubor P., Isah, A., Yusuf D. (2013) Proximate Composition and Some Functional Properties of Flour from the Kernel of African Star apple (Chrysophyllual albidum). International Journal of Agricultural Policy and Research, 1(3) 62-66

Appiah F., Asibuo JY., Kumah P. (2011) Physical and Functional Properties of Bean Flours of Three Cowpea (Vigna unguiculata L.) varieties in Ghana. African Journal of Food Science 5(2) 100-104.

Araki E., Ikeda MT., Ashida K., Tanaka K., Yanaka M., Iida S. (2009) Effects of rice flour properties on specific loaf volume of one-loaf bread made from rice flour with wheat vital gluten. Journal of Food Science and Technology Research, 15(4) 439 - 448.

Arendt EK., Moore MM. (2006) Gluten-free cereal-based products, in Bakery Products Science and Technology, In: H. Corke, I. de Leyn, W. K. Nip, N. Cross, and Y. H. Hui, Eds. pp. 471-495.

Ayo J.A., Nkama I.(2004) Effect of Acha (Digitaria exils) grain flour on the physico-chemical and Sensory Properties of Bread. International Journal of Food Properties, 7(3) 561-569

Akubor JE., Obiegbujna CN., Ishiwu J., Ndife J. (2013) Effect of substituting sugar with date palm pulp meal on the physicochemical, organoleptic and storage properties of bread. African Journal of Food Science 7(6) 113-119.

Blanshard JMV. (1987) The significance of the structure and function of the starch granules in baked products. Chemistry and Physics of Baking. J.M.V. Blanshard, P.J. Frazier, and T. Galliard eds, The Royal Society of chemistry, Burlington House: London. pp. 1-13

Bloksma AH. (1990) Rheology of the bread making process. Cereals Foods World 35:226-236.

Coffman C., Garcia VV. (1977). Functional properties of protein isolate from mung-bean flour. Journal of Food Technology, $12473-484$.

Dewettinck K, Van BF, Kuhne B, Walle V, Courtens T, Gellynck X (2008) Nutritional value of bread influence of processing, food interaction and consumer perception. Journal of Cereal Sciences 48 243-257.

Eduardo M., Svanberg U., Ahrné L. (2014). Consumers' acceptance of composite cassava maize-wheat breads using baking improvers. African Journal of Food Science, 8(7) 390-401.

Eduardo M., Svanberg U., Ahrné L. (2016) Effect of Hydrocolloids and Emulsifiers on the Shelf Life of Composite Cassava-Maize-Wheat Bread after Storage. Food Science and Nutrition, 2(4) 636-644.

Eggleston G., Omoaka PE., Arowosegbe AU. (1993) Flour, Starch and Composite Bread making Quality of Various Clones. Journal of the Science of Food and Agriculture 62 49-59.

Elleuch, M., Bedigian, D., Roiseux, O., Besbes, S., Blecker, C. and Attia, H. (2011) Dietary fibre and fibre-rich by-products of food processing: Characterization, technological functionality and commercial applications. Food Chemistry, 124 411-421.

Fan T, Mitchell JR., Blanshard JMV. (1999) A model for the oven rise of dough during baking. Journal of Food Engineering, 41 69-77.

Fernande De Tonella ML., Berry JW. (1989) Rheological Properties of Flour and Sensory Characteristics of Bread made from Germinated Chick Peas. International Journal of Food Science and Technology, 24(1).

Food and Agriculture Organization of the United Nations (2013) Save and Grow Cassava: A Guide to Sustainable Production Intensification, Food and Agriculture Organization of the United Nations, Rome, Italy.

Giami GY., Amasisi T., Ekiyor G. (2004) Comparison of bread making properties of composite flour from kernel of roasted and boiled African bread fruit (Treculia Africana) seed. Journal of Materials Research, 1 16-25.

Gomez M., Ronda F., Blanco CA., Caballero PA., Apestegula A. (2003) Effect of dietary fibre on dough rheology and bread quality. European Food Research and Technology, 216 51-56.

Gómez M, Real S, Rosell C, Ronda F, Blanco C, Caballero P (2004) Functionality of different emulsifiers on the performance f bread making and wheat bread quality. European Food Research Technology 219(2) 145-150 .

Hsu, C. L., Hurang, S. L., Chen, W., Weng, Y. M., Tseng, C. Y. (2004) Qualities and antioxidant properties of bread as affected by the incorporation of yam flour in the formulation. International Journal of Food Science and Technology, 39 231-238

International Standard Organization (ISO) (1981) Sensory Analysis Vocabulary, Part 4, International Organization for Standardization, Geneva.

Kinsella JE. (1976) Functional properties of Protein Foods. Critical Review in Science and Nutrition, 1 219- 229.

Kohajdová Z., Karovičová J. (2008) Influence of Hydrocolloids on quality of baked goods. Acta Scientiarium Polonorum Technology Aliment, 7(2) 43-49.

Leelavathi K., Haridas Rao P., Indrani D., Shurpalekar SR. (1984) Physico-chemical Changes in whole wheat flour (Atta) during Storage. Journal of Food Science Technology, 21(2) 68-71.

Luyten H., Van-Vliet T. (1995) Fracture properties of starch gels and their rate of starch gels and their rate dependency. Journal of Texture Studies, $26281-298$.

Mepba HD., Eboh L., Nwaojigwa SU. (2007) Chemical composition, functional and baking properties of wheat-plantain composite flours. African 
Journal of Food Agriculture, Nutrition and Development 7(1) 1-22.

Martin ML., Zeleznak KJ., Hoseney RC. (1991) A mechanism of bread firming. I. Role of starch swelling. Cereal Chemistry, $68489-503$.

Nwosu, J. N., Onuegbu, N. C., Kabuo, N. O., \& Okeke, M. O. (2010) The effect of steeping with chemicals (Alum and Trona) on the proximate and functional properties of pigeon pea (Cajanus cajan) flour. Pakistan Journal of Nutrition, 9 762-768.

Nasir O., Artunc F., Saeed A., Kambal MA., Kalbacher H., Sandulache D., Boini KM., Jahovic NJ., Lang F. (2008) Journal of Renal Nutrition, 18 230-238.

Ohiagu, C.E., Ahmed, A. Orakwe, F.C., Maurya, P., Ajayi, O., Falaki, A. and Kaul, N. (1987) A National Wheat Production Strategy: 1987 -1996. Prepared by Cereal Research Programme, IAR, ABU, Zaria for FACU 67pp14.Food and Agriculture Organization of the United Nations, Save and Grow Cassava: A Guide to Sustainable Production Intensification, Food and Agriculture Organization of the United Nations, Rome, Italy, 2013.

Olabanji OG., Omeje M.U., Mohammed I., Ndahi WB., Nkema I. (2007) Wheat: In Cereal Crops of Nigeria: Principles of Production and Utilization, xxii, 337 (Idem, N.U.A. and F.A. Showemimo edited) pp $230-249$.

Omueti O., Otegbayo B., Jaiyeola O., Afolabi O. (2009) Functional Properties of Complementary Diets Developed from Soybean (Glycine max), Groundnut (Arachis hypogeal) and Crayfish (Macrobrachium spp). Journal of Environmental, Agricultural and Food Chemistry, 8(8) 563-573.

Okaka JC., Potter NN. (1977) Functional and storage properties of cowpea-wheat flour blends in bread making. Journal of Food Science, 42 828-833. Osungbaro TO. (1990) Effect of differences in variety and dry milling of maize on texture characteristics of Ogi. Journal of Food and Agriculture, $541-11$.

Plyer EJ. (1988) Baking Science and Technology. 3rd edition, Merriam, Kansas USA, Sosland publishing Co., pp. 998-1012.

Qiu CH., Zhao M., McClement DJ. (2015) Improving the stability of wheat protein-stabilized emulsions: Effect of pectin and xanthan gum addition. Food Hydrocolloids, 43 377-387.

Rao HP., Hemamalini R. (1991) Effect of incorporating wheat bran on rheological characteristics and bread making quality of flour. Journal of Food Science and Technology 28 92-97.

Rodge AB., Sonkamble SM., Salve RV., Syed Imran Hashmi (2012) Effect of hydrocolloid (guar gum) incorporation on the quality characteristics of bread. Journal of Food Processing \& Technology, 3(2) 1-7.

Sanni LO., Kosoko SB., Adebowale AA., Adeoye RJ. (2004) The Influence of Palm Oil and Chemical Modification on the Pasting and Sensory Properties of Fufu Flour. International Journal of Food Properties, 7 229-237

Schiraldi A., Fessas D. (2000) Mechanism of Staling. In C. Pavinee, Vodovotz (eds), Bread Staling, New York, CRC Press, Inc. pp. 2-10.

Šedivý P., Dostál J., Kovař́iková D., Martinek V. (2013) Pekařská technologie I. Suroviny (The bakery technology I. Ingredients). Effect of the addition of hydrocolloids on the rheological and baking properties of the products with added spelt flour (Triticum spelta L.) pp. 238.

Selomulyo VO., Zhou W. (2007) Frozen bread dough: Effects of freezing storage and dough improvers. Journal of Cereal Science, 45 1-17.

Shittu TA., Raji AO., Sanni LO. (2007) Bread from composite cassava-wheat flour: I. Effect of baking time and temperature on some physical properties of bread loaf. Food Research International, 40 280-290.

Shittu TA, Aminu RA., Abulude EO. (2009) Functional effects of xanthan gum on composite cassava-wheat dough and bread, Food Hydrocolloids, 23(8) 2254-2260.

Skara N., Novotni D., Cukelj N., Smerdel B., Curic D. (2013) Combined effects of inulin, pectin and guar gum on the quality and stability of partially baked frozen bread. Food Hydrocolloids, 30(1) 428-436.

Sosulski F., Humbert ES., Bui K., Jones JD. (1976) Functional properties of Rapeseed Flours, Concentrates and Isolate. Journal of Food Science, 41(6) 1349-1352. 